\title{
OBITUARY
}

\section{Theodor Axenfeld}

Theodor Axenfeld was born in June, 1867, in Smyrna, the son of Julius Axenfeld, a missionary. He was educated in Germany and studied medicine at the Univerisities of Marburg and Berlin. He took his M.D. degree in 1890. He studied ophthalmology under Prof. Schmidt-Rimpler and more especially Prof. Uhthoff.

He worked at pathology with Marchand and bacteriology with Rubner and C. Fraenkel. He spent the winter of $1894 / 95$ in the laboratory of von Helmholtz.

During the years 1895/97 he was Privat-Dozent at the Universities of Marburg and Breslau and in 1897 he was called to the University of Rostock as Professor of Ophthalmology and Director of the University Eye Clinic. He remained in Rostock until 1901 when he accepted a call from the University of Freiburg and here he remained for the rest of his life, 29 years, in spite of many attempts of other universities to obtain his services, notably Berlin after the death of von Michel-Vienna after the retirement of Fuchs-Heidelburg after Leber, Breslau after Uhthoff, etc.

The chief reasons for his refusal of these calls were that at Freiburg he had an admirably designed and equipped ophthalmological institute and that being a small town he was not unduly worried by a large number of private patients. $\mathrm{He}$ always maintained the point of view that chiefs of clinics should keep themselves as free from private practice as possible in order that they should be able to devote themselves to scientific work.

It was to this aspect of ophthalmology that he gave most of his time and to which he made many notable contributions. His first important paper was "Suppurative Metastatic Ophthalmia," published in 1894. This paper is a model of what a completed investigation should be. It gives a detailed picture of the disease, the bacteriological findings, and the pathological changes, based upon experimental and clinical data, and remains to-day the classical paper on this subject. It was awarded the Graefe Prize by the Heidelburg (now German) Ophthalmological Society. This was followed in 1895 by the "Etiology of the Serpiginous Ulcer of the Cornea," in which he showed the important rôle played by the pneumococcus in the production of this condition. Then in 1896 came the discovery of epidemic pneumococcus conjunctivitis and diplo-bacillary conjunctivitis (simultaneously with Morax).

In 1902, based upon the enormous experience acquired in Rostock, he published "Das Trachom," an exposition of all the 
various manifestations and complications of this plague and the best means of dealing with it, both individually and as a social question.

The humanitarian and philanthropic aspect of the man was shown first in 1905 when he used as his subject for a Rectoral address " Blindness and Care of the Blind." In this subject he showed a continuous interest and always used his great influence to bring about an amelioration of the conditions of life for the blind in all social levels.

From 1901 onwards he became interested in tuberculosis of the eye and many articles on this subject came from his laboratory and in 1909 the description of the condition "Periphlebitis retinae tuberculosa." In 1907 appeared the book "Ophthalmological Bacteriology," which was translated into English in 1908 by MacNab. In 1908 he published in the French language his work "Le catarrhe printanier."

In 1909 appeared the " Textbook of Ophthalmology" which went through many editions, the last one, the seventh, in 1923. This book has been translated into many languages.

The number of papers and books published under his own name amounts to nearly 200 and besides this there are a larger number which, emanating from his clinic and laboratory, owe their inspiration to him, but bear the names of those who worked under him.

In 1899 he became associated with Zehender in the editorship of the " Klinische Monatsblätter für Augenheilkunde." In the following year Zehender retired and this important publication has been carried on by Axenfeld alone from that time. Under his editorship it became the most widely read German ophthalmological periodical and was characterized by the importance of its original contributions, by the general excellence of its editing and by a sane appreciation of all the problems of ophthalmology.

In 1915 he assumed jointly with Elschnig the editorship of the big Graefe-Saemisch "Handbuch der Augenheilkunde" and in that year appeared the first edition of the "Operationslehre" to be followed in 1922 by a second edition. In 1898-1928 appeared the volumes "Pathology of the Eye" as part of the "Ergebnissen" of Lubarsch and Ostertag.

Axenfeld was the recipient of many honours, both in his own and foreign countries. Besides many ribbons and stars of knightly orders, the University of Freiburg made him first Dean of Faculty of Medicine and later, Rector of the University.

In 1925 he became President of the German Ophthalmological Society and he was German representative on the League of Red Cross Societies for the Prevention of Blindness. He was an honorary member of many foreign medical societies and in 
1929 was awarded the Lucien Howe gold medal of the American Ophthalmological Society for his "Great services to Ophthalmology." He had previously received the Graefe 'Medal of the German Ophthalmological Society.

In 1928, he and Wessely represented Germany at the meeting of delegates which arranged the 1929 International Congress at Amsterdam, and those who met him at that congress will remember how active he was, how interested in everything and how much he devoted himself to making that congress the success it was.

He had intended being present at the Jubilee Meeting of the Ophthalmological Society of the United Kingdom this year but was unable to do so as he had accepted an invitation to visit the Universities of Japan. From this visit he returned in the middle of May and resumed his work, but it was only to be for a short time. An illness supervened and he died on July 29 in his 64th year.

Axenfeld's great characteristics were a deeply religious feeling, honesty of purpose, uprightness of character and an extraordinary power of concentration and work. This was combined with great intellectual ability and a critical faculty. which led him to be an indefatigable searcher after the truth. As a teacher he was unexcelled and to all those who had the privilege of working with him he was a constant source of inspiration-his example stimulated all so that they gave of their best for him.

His death while still in possession of his full mental vigour is an irreparable loss to ophthalmology and he will be mourned by a great circle of pupils and friends all over the world.

He leaves behind a wife, three daughters and one son and to them we would express our deepest sympathy.

\section{Arthur Robertson Brailey}

WE regret to record the death of A. R. Brailey in tragic circumstances when the yacht "Islander" was lost with all hands off the Cornish coast in a gale on August 21. The younger son of Dr. W. A. Brailey, Ophthalmic Surgeon to Guy's Hospital, whom he much resembled in face and figure, Brailey was born in October, 1877. Educated at Westminster, he gained a scholarship at Downing College, Cambridge, and completed his medical course at Guy's Hospital, where he gained a University entrance scholarship. He also spent some time in Vienna. Qualifying at "the Colleges" in 1903, he took the M.B., M.C., Cantab. in 1904, having in the previous year obtained his M.A., B.Ch. His F.R.C.S. dated from 